\title{
ANALISIS FAKTOR YANG BERHUBUNGAN DENGAN KEPATUHAN PSK WARIA DALAM MENCEGAH PENULARAN HIV/AIDS DI SURABAYA.
}

\author{
A cross sectional study in transsexual prostitute of Surabaya
}

\author{
Oleh; Syiddatul Budury
}

The obedience to prevent HIV/AIDS spreading was needed to make HIV/AIDS epidemic doesn't come true. Transsexual prostitution is one of community that sensitively to HIV/AIDS contagious. They have to prevent it to their self with using condom, never swallow the sperm and do screening test regularly.

This study was aimed to analyze factors correlating with transsexual prostitutes obedience in preventing a HIV/AIDS contagion. This study used cross sectional design. The population is all transsexual prostitute. Total sample was 40 respondent, selected using purposive sampling. The dependent variable is the obedience, and the independent variable are knowledge, economic motivation, motivation to make customer satisfaction. The data collected using questionnaire. The data was analyzed using spearman's rho correlation test with level of significance of $\rho=0.05$

Result revealed that between knowledge with the obedience to prevent HIV/AIDS contagion has no correlation, with $\rho=0.442$ and $r=(-) 0.125$. and between economic motivation with the obedience to prevent HIV/AIDS contagion has no correlation with $\rho=0.875$ and $r=0.026$. motivation to make customer satisfaction with the obedience to prevent HIV/AIDS contagion has no correlation with $\rho=0.889$ and $r=(-$ 0.023

It can be concluded that the knowledge, economic motivation, motivation to make customer satisfaction is not always influencing to the transsexual prostitute obedience to prevent HIV/AIDS contagion, because its all about get so much money to survive. We hope that the transsexual prostitute will get general check up or screening and better measurement tool to obtain more accurate result.

Key Word : Obedience, knowledge, economic motivation, customer satisfaction, HIV/AIDS.

\section{PENDAHULUAN}

Jumlah kasus HIV/AIDS yang terus meningkat secara signifikan menempatkan Indonesia pada peringkat tiga sebagai negara yang mempunyai tingkat penularan HIV/AIDS paling tinggi (WHO-UNAIDS:2005). Kondisi ini jika dibiarkan akan menjadikan HIV sebagai sebuah epidemi.

Di Jakarta pada tahun 2007 ditemukan sebanyak 5.7\% dari 1500 Pekerja Seks Komersial (PSK) Waria yang menderita AIDS, sedang pada tahun 2004 menjadi 22\%. Hasil Surveilans Terpadu Biologis dan Perilaku (STBP) tahun 2011 (Kemenkes, 2014) menunjukan bahwa prevalensi HIV tertinggi terdapat di kelompok pemakai narkoba suntik lalu diikuti kelompok waria. Peningkatan kasus HIV/AIDS tidak lepas dari perilaku PSK Waria yang tergolong pada kelompok beresiko misalnya melakukan hubungan seks secara oral dan anal tanpa memakai pengaman atau kondom, serta "mandi kucing" yang akan berakhir pada kegiatan oral dan anal seks, sehingga rentan terkena HIV/AIDS. PSK Waria sebagai salah satu kaum homoseksual, menempati peringkat tiga setelah kelompok heteroseksual dan Injecting Drug User (IDU) dalam kasus HIV/AIDS menurut faktor resiko (Depkes : 2011). Salah satu upaya yang telah dilakukan oleh pemerintah, Lembaga Swadaya Masyarakat (LSM) dan sektor swasta dalam rangka pencegahan penularan HIV/AIDS adalah pendidikan kesehatan yang menekankan pada kesadaran pentingnya perilaku safe sex, dengan menyediakan berbagai informasi tentang HIV/AIDS melalui seminar, internet, koran, poster, film serta pemberian dukungan pada ODHA (Orang Dengan HIV/AIDS), pelaksanaan skrining HIV/AIDS, dan penyediaan kondom. Namun pada kenyataannya walau sudah mendapat informasi tentang HIV/AIDS terbukti tidak semua PSK Waria melakukan perilaku Safe Sex ( memakai kondom atau pelindung lain) sehingga angka kejadian HIV/AIDS terus meningkat. Hal ini memberi suatu pemikiran bahwa terdapat faktor-faktor yang berhubungan 
dengan kepatuhan dalam mencegah pemberian HIV/AIDS pada PSK waria yang belum teridentifikasi.

Perilaku seksual PSK waria yang tidak aman atau berhubungan oral dan anal seks tanpa kondom akan menyebabkan peningkatan jumlah kasus HIV/AIDS. Gambaran ini didukung oleh data dari AusAids bahwa mayoritas waria memberikan jasa seks, survei di Bali menyebutkan bahwa 95\% waria memberikan jasa seks (Harahap, 1999). Saat ini pada tingkat nasional terdapat 7.098 kasus HIV/AIDS yang terdaftar namun jumlah sebenarnya diperkirakan sekitar 13.000 kasus (BKKBN:2005. Keadaan ini dipengaruhi juga oleh tingkat mobilitas (perpindahan dari sutu kota ke kota lain) PSK waria yang cukup tinggi (Puspitosari:2005) sehingga penularan HIV/AIDS bisa lebih meluas. Dampak dari penularan HIV yang akan menjadi HIV positif, AIDS dan kemungkinan yang terburuk adalah kematian.

PSK waria ibarat dua sisi mata uang karena bisa berfungsi sebagai sumber penularan HIV/AIDS serta pihak yang tertular. Maksud dari pernyataan ini adalah pertama sebagai sumber penularan HIV/AIDS serta pihak yang tertular. Jika PSK waria melakukan perilaku seks secara oral dan anal seks (termasuk juga mandi kucing) tanpa memakai kondom, maka mereka akan menulari para user (pemakai jasa) yang belum terjangkit HIV melalui jalan oral atau anal seks, sedang para pemakai jasa dari kaum heteroseksual, bisa pria tulen, biseks atau gay. Jika para pemakai berhubungan lagi dengan orang lain (isteri, suami, PSK lain) maka mereka akan juga menularinya. Kedua, PSK waria sebagai pihak yang tertular, jika awalnya mereka bersih dari HIV, namaun kemudian "dipakai" oleh pemakai yang HIV positif atau AIDS maka mereka akan tertular dan selanjutnya akan menulari para pemakai lainnya, sehingga keadaan tersebut menjadi suatu mata rantai sumber penularan yang paling produktif . akibatnya jika seseorang sudah mengidap HIV positif selanjutnya sesuai dengan periode jendela (window period) dari virus akan menjadi AIDS. Sampai saat ini AIDS belum ditemukan obatnya. Obat ARV (Anti Rota Virus) yang saat ini diberikan pada pengidap AIDS hanya berfungsi sebagai penghambat replikasi virus dalam tubuh, dan bisa meningkatkan daya tahan tubuh sehingga penderita AIDS akan mengalami kematian sebagai akhir dari periode AIDS.

Strategi nasional penanggulangan HIV/AIDS 2003/2007 yang ditetapkan kementerian kesejahteraan rakyat membuat tujuh area prioritas yaitu pencegahan HIV/AIDS, perawatan dan pengobatan serta dukungan terhadap ODHA, surveilans HIV/AIDS dan Infeksi Menular Seksual (IMS), kegiatan penelitian, lingkungan yang kondusif, koordinasi multipihak, dan penanggulangan yang berkesenimabunga. Sejalan dengan strategi nasional tersebut terutama poin pertama (pencegahan) maka sangat diharapkan agar para PSK waria melakukan perilaku seksual yang aman dan perilaku sehat (memakai kondom) dalam mencegah HIV/AIDS dari penelti mengharapkan agar peran aktif dari LSM, pemerintah dan sektor swasta perlu ditingkatkan dalam melaksanaan skrining tes HIV/AIDS, serta perlunya kesadaran dari individu (PSK waria) untuk mencegah HIV/AIDS.

\section{METODE}

Penelitian ini bersifat analitik korelasional yang dilakukan dengan menggunakan metode cross sectional. Populasi dalam penelitian ini adalah semua PSK waria yang bekerja di tempat mangkal PSK waria di Surabaya, yaitu di jalan Irian Barat, area pemakaman China Kembang Kuning, Area Pasar Turi. Besar sampel dalam penelitian ini adalah 40 responden. Penelitian ini menggunakan purposive sampling.

HASIL

berikut :

1) Distribusi responden berdasar pendidikan

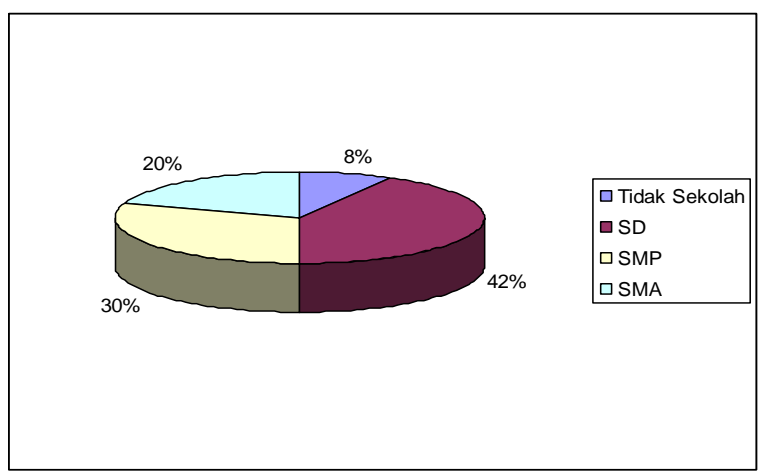

Gambar 1 Distribusi Responden Berdasar Tingkat Pendidikan PSK Waria di Wilayah Kota Surabaya Oktober 2015

Dari gambar 1 menunjukkan bahwa mayoritas $42 \%$ tingkat pendidikan responden adalah SD (Sekolah Dasar).

2) Distribusi responden berdasar umur

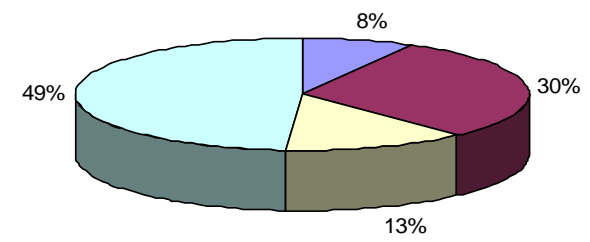


Gambar 2 Distribusi Responden Berdasar Umur PSK Waria di Wilayah Kota Surabaya Oktober 2015

Dari gambar 2 menunjukkan bahwa mayoritas $49 \%$ berusia di atas 35 tahun.

3) Distribusi responden berdasar penghasilan

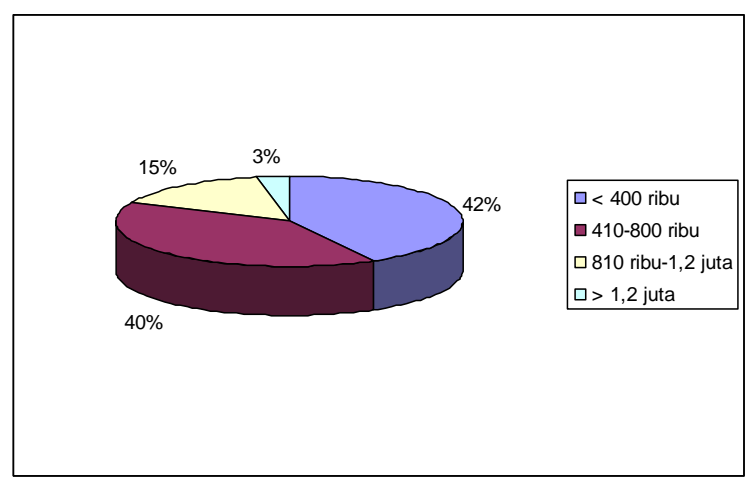

Gambar 3 Distribusi Responden Berdasar Penghasilan PSK Waria di Wilayah Kota Surabaya Oktober 2015

Dari gambar 3 dapat diketahui bahwa mayoritas $42 \%$ mempunyai penghasilan < 400 ribu rupiah.

4) Distribusi responden berdasar lama menjadi PSK

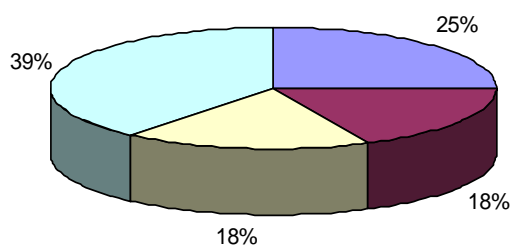

$18 \%$

Gambar 4 Distribusi Responden Berdasar Lama Menjadi PSK, pada PSK Waria di Wilayah Kota Surabaya Oktober 2015

Dari gambar 4 dapat diketahui bahwa terdapat $39 \%$ telah menjadi PSK selama lebih dari 10 tahun.
5) Distribusi responden berdasar pekerjaan selain menjadi PSK

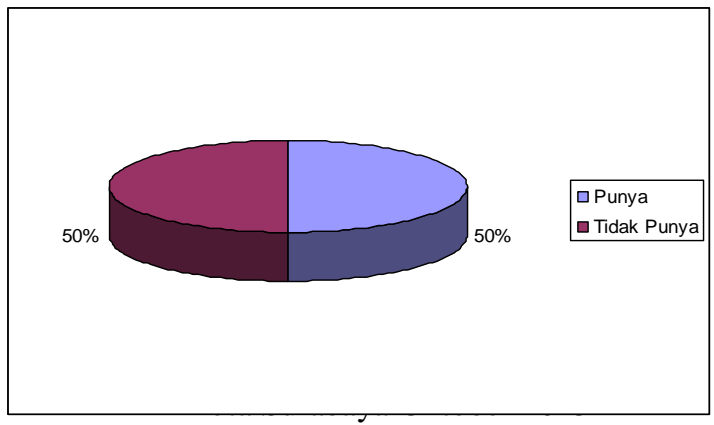

Dari diagram 5 menunjukkan bahwa $50 \%$ mempunyai pekerjaan lain selain menjadi PSK, dan 50 yang hanya menjadi PSK sebagai pekerjaan utama. Dari 20 responden yang mempunyai pekerjaan, jenis pekerjaannya diklasifikasikan sebagai berikut : bekerja di salon, menjadi pedagang, penari ular, pengamen, koki, pembantu rumah tangga panggilan.

6) Distribusi responden berdasar faktor membiayai hidup orang lain

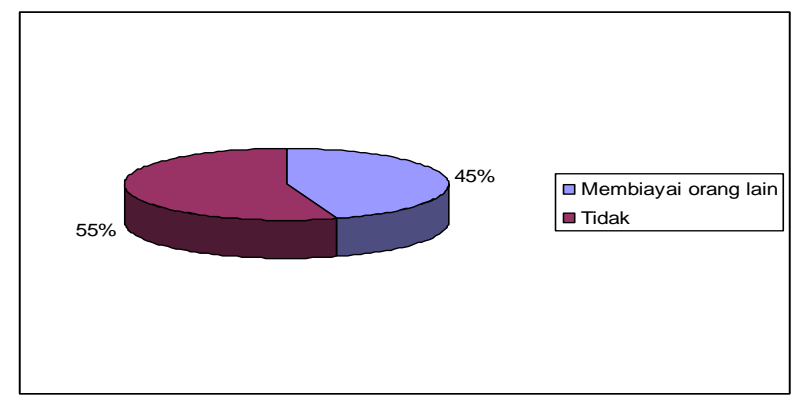

Gambar 6 Distribusi Responden Berdasar Faktor Membiayai Hidup Orang Lain pada PSK Waria di Wilayah Kota Surabaya Oktober 2015

Dari diagram di atas menunjukkan bahwa mayoritas $55 \%$ PSK waria membiayai hidupnya sendiri.

7) Distribusi responden berdasar cara memperoleh kondom
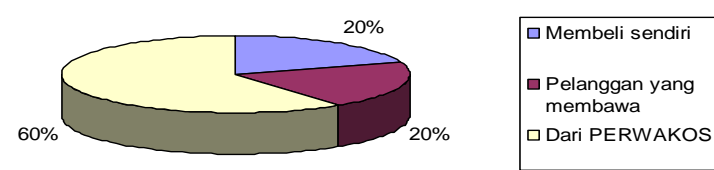
Gambar 7 Distribusi Responden Berdasar Cara Memperoleh Kondom pada PSK Waria di Wilayah Kota Surabaya Oktober 2015

Dari gambar 7 menunjukkan bahwa mayoritas $60 \%$ responden mendapatkan kondom secara gratis dari PERWAKOS.

\section{Variabel yang Diukur}

1) Pengetahuan

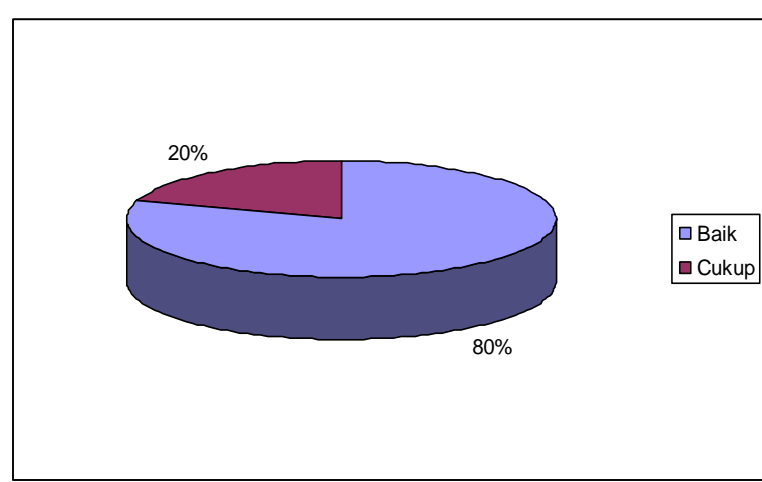

Gambar 8 Data Tingkat Pengetahuan tentang HIV/AIDS pada PSK Waria Kota Surabaya Oktober 2015

Dari gambar 8 menunjukkan bahwa mayoritas $80 \%$ responden memiliki tingkat pengetahuan yang baik.

2) Motivasi ekonomi

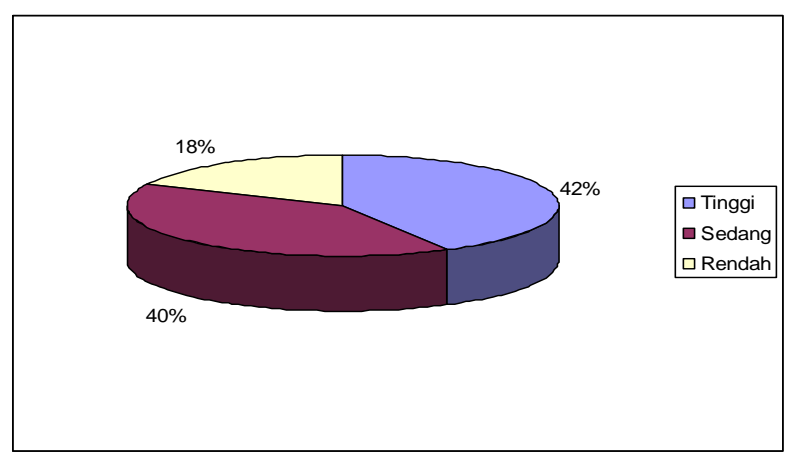

Gambar 5.9 Data Tingkat Motivasi Ekonomi pada PSK Waria Kota Surabaya Oktober 2015

Dari gambar 9 menunjukkan bahwa 42 $\%$ responden mempunyai motivasi ekonomi yang tinggi.

3) Motivasi memuaskan pelanggan

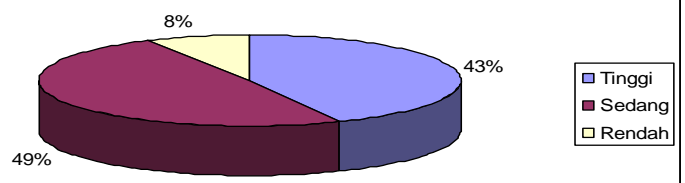

Gambar 10 Data Tingkat Motivasi Memuaskan Pelanggan PSK Waria Kota Surabaya Oktober 2015

Dari gambar 10 menunjukkan bahwa mayoritas $49 \%$ responden mempunyai motivasi memuaskan pelanggan yang sedang.

4) Tingkat kepatuhan dalam mencegah penularan HIV/AIDS

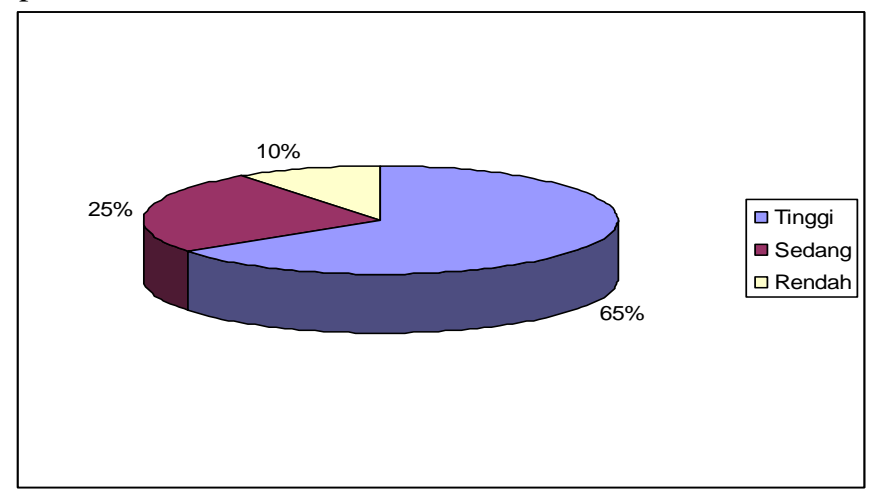

Gambar 11 Data Tingkat Kepatuhan dalam Mencegah Penularan HIV/AIDS PSK Waria Kota Surabaya Oktober 2015

Dari gambar 12 menunjukkan bahwa $65 \%$ responden memiliki tingkat kepatuhan yang tinggi.

Data responden mengenai perilaku kepatuhan dalam mencegah penularan HIV/AIDS didapatkan data sebagai berikut : terdapat $25 \%$ responden yang selalu memakai kondom saat berhubungan seksual secara oral dan anal. 67,5\% responden yang memakai kondom hanya kadang-kadang dengan alasan; tergantung permintaan pelanggan (terkadang pelanggan membawa kondom sendiri), besarnya imbalan jasa, penampilan pelanggan, emosi (perasaan) PSK sendiri, sedangkan $7,5 \%$ responden mengaku tidak suka memakai kondom dengan alasan tidak nyaman dan tuntutan ekonomi karena faktor umur yang sudah tua. Sebanyak 87,5\% responden mengakui tidak pernah menelan air mani pelanggan dengan alasan merasa jijik dan menjaga kesehatan, 
dan $12,5 \%$ responden lainnya mengaku kadang-kadang mengaku menelan kadangkadang menelan air mani pelanggan dengan alasan bahwa kadang mereka ingin menelannya terutama jika pelanggan mereka dari kalangan kaum muda dengan alasan ai rmani kaum muda terasa seperti degang, untuk rasa air mani yang pahit biasanya karena pelanggan minum minuman beralkohol. Ketika PSK waria mempunyai keluhan dengan alat kelamin (merah, panas, luka, nyeri saat BAK, mengeluarkan nanah) : $80 \%$ responden langsung mencari pertolongan pengobatan (dokter, pengobatan alternatif). 12,5\% responden tidak langsung mencari pengobatan, mereka hanya kadangkadang saja, dengan alasan jika uang mereka cukup mereka akan mencari pengobatan, sedangkan $7,5 \%$ tidak pernah diobati dengan keyakinan akan sembuh sendiri, kalaupun sampai parah mereka hanya akan minum jamu.

5) Hubungan antara tingkat pengetahuan dengan kepatuhan dalam mencegah penularan HIV/AIDS

Tabel 1 Data Hubungan Tingkat Pengetahuan dengan Kepatuhan PSK Waria dalam mencegah penularan HIV/AIDS di Surabaya Oktober 2015

\begin{tabular}{|c|c|c|c|c|c|c|c|c|}
\hline \multirow[b]{2}{*}{$\begin{array}{c}\text { Pengeta } \\
\text { huan }\end{array}$} & \multicolumn{6}{|c|}{ Tingkat Kepatuhan } & \multirow[b]{2}{*}{ Total } & \multirow[b]{2}{*}{$\%$} \\
\hline & Tinggi & $\%$ & $\begin{array}{l}\text { Sed } \\
\text { ang }\end{array}$ & $\%$ & $\begin{array}{c}\mathbf{R e} \\
\text { nda } \\
\mathbf{h}\end{array}$ & $\%$ & & \\
\hline Baik & 19 & 47,5 & 10 & 25 & 3 & 7,5 & 32 & 8 \\
\hline Cukup & 7 & 17,5 & & & 1 & 2,5 & 8 & 2 \\
\hline \multicolumn{9}{|c|}{ Uji Spearman's rho : $(\mathrm{r})=-0,125 \quad \rho=0,442 \mathrm{~N}=40$} \\
\hline
\end{tabular}

Sesuai dengan hasil analisa Spearman's rho didapatkan tingkat kemaknaan $\rho=0,442$ dan koefisien $\mathrm{r}=$ 0,125 . Artinya bahwa tidak ada hubungan antara pengetahuan dengan kepatuhan dalam mencegah penularan HIV/AIDS pada PSK waria di wilayah Kota Surabaya.

6) Hubungan antara motivasi ekonomi dengan kepatuhan dalam mencegah penularan HIV/AIDS
Tabel 2 Data Hubungan Motivasi Ekonomi dengan Kepatuhan PSK Waria dalam mencegah penularan HIV/AIDS di Surabaya Oktober 2015

\begin{tabular}{|c|c|c|c|c|c|c|c|c|}
\hline \multirow{2}{*}{$\begin{array}{l}\text { Motivasi } \\
\text { Ekonomi }\end{array}$} & \multicolumn{6}{|c|}{ Tingkat Kepatuhan } & \multirow{2}{*}{$\begin{array}{c}\text { Tot } \\
\text { al }\end{array}$} & \multirow[b]{2}{*}{$\%$} \\
\hline & Tinggi & $\%$ & Sedang & $\%$ & $\begin{array}{c}\text { Rend } \\
\text { ah }\end{array}$ & $\%$ & & \\
\hline Tinggi & 12 & 30 & 5 & 12,5 & $\sqrt{ }$ & $\sqrt{ }$ & 17 & $\begin{array}{c}42 \\
5\end{array}$ \\
\hline Sedang & 9 & 22,5 & 4 & 10 & 3 & 7,5 & 16 & 40 \\
\hline Rendah & 5 & 12,5 & 1 & 2,5 & 1 & 2,5 & 7 & $\begin{array}{c}17, \\
5\end{array}$ \\
\hline \multicolumn{7}{|c|}{$\begin{array}{l}\text { Uji Spearman's rho : }(r)=0,026 \\
40\end{array}$} & \multicolumn{2}{|c|}{$\mathrm{N}=$} \\
\hline
\end{tabular}

Berdasarkan Tabel 2 menunjukkan hasil analisa Spearman's rho dengan tingkat kemaknaan $\rho=0,875$ dan koefisien $\mathrm{r}=0,026$ maka disimpulkan bahwa tidak ada hubungan antara motivasi ekonomi dengan kepatuhan dalam mencegah penularan HIV/AIDS pada PSK waria di Surabaya.

7) Hubungan antara motivasi memuaskan pelanggan dengan kepatuhan dalam mencegah penularan HIV/AIDS

Tabel 3 Data Hubungan Motivasi Memuaskan Pelanggan dengan Kepatuhan PSK Waria dalam mencegah penularan HIV/AIDS di Surabaya Oktober 2015

\begin{tabular}{|l|c|c|c|c|c|c|c|c|}
\hline $\begin{array}{c}\text { Motivasi } \\
\text { Memuaskan } \\
\text { Pelanggan }\end{array}$ & \multicolumn{5}{|c|}{ Tingkat Kepatuhan } & \multirow{2}{*}{ Total } & $\%$ \\
\cline { 2 - 9 } & Baik & Cukup & $\%$ & Kurang & $\%$ & & \\
\hline Tinggi & 10 & 25 & 4 & 10 & 3 & 7,5 & 17 & 42,5 \\
\hline Sedang & 15 & 37,5 & 4 & 10 & 1 & 2,5 & 20 & 50 \\
\hline Rendah & 1 & 2,5 & 2 & 5 & - & - & 3 & 7,5 \\
\hline Uji Spearman's rho : (r)=-0,023 $\rho=0,889$ & \multicolumn{7}{|c|}{$\mathrm{N}=40$} \\
\hline
\end{tabular}


Berdasarkan Tabel 3 menunjukkan hasil analisa Spearman's rho dengan tingkat pemaknaan $\rho=0,889$ dan koefisien $\mathrm{r}=$ 0,023 maka disimpulkan bahwa tidak ada hubungan antara motivasi memuaskan pelanggan dengan kepatuhan dalam mencegah penularan HIV/AIDS pada PSK waria Kota Surabaya.

\section{PEMBAHASAN}

Pengetahuan adalah salah satu faktor yang mendorong seseorang untuk berprilaku, dalam hal ini untuk berprilaku patuh. Hasil penelitian ini bertentangan dengan pendapat Notoatmodjo (2003) bahwa pengetahuan atau kognitif merupakan domain yang sangat penting untuk terbentuknya suatu tindakan seseorang (overt behavior). Pada kelompok tertentu berlaku juga bahwa semakin besar akibat yang tidak menyenangkan bagi dirinya dan orang lain akibatnya semakin tinggi tingkat kepatuhan individu tersebut.

Pengetahuan dari sebagian besar responden tentang HIV/AIDS diperoleh dari PERWAKOS, yang secara aktif memberikan penyuluhan tentang HIV/AIDS, selain itu adanya berbagai media seperti TV, koran, majalah dan internet juga menambah pengetahuan tnetang HIV/AIDS (terutama tentang gejala, penularan dan pencegahan). Pada hasil penelitian ini, tingkat pengetahuan responden tentang HIV/AIDS sudah baik, demikian juga tingkat kepatuhan. Namun karena penelitian ini berada pada lingkup sosial sehinga keadaan bahwa tingkat pengetahuan dan kepatuhan dalam mencegah HIV/AIDS pada PSK waria tidak ada hubungan bisa terjadi, mengingat bahwa kepatuhan tidak hanya dipengaruhi oleh besarnya pengetahuan. Pengetahuan yang sudah baik tentang HIV/AIDS pada PSK waria anggota PERWAKOS belum menjamin akan menghasilkan kepatuhan yang baik, karena seorang PSK waria memiliki banyak motif dan tekanan yang ditanggung.

Pengetahuan yang tidak berhubungan dengan kepatuhan dalam mencegah penularan HIV/AIDS pada penelitian ini bisa terjadi karena beberapa faktor, pertama, adanya dorongan kebutuhan biologis (seksual), walau mereka mengetahui tentang bahaya HIV/AIDS tapi ketika dorongan nafsu seksual meningkat disertai keinginan untuk merasakan kepuasan maka mereka akan mengeyampingkan perilaku kepatuhan. Kedua, kebutuhan psikis (rasa kasih sayang), mayoritas pengakuan dari PSK waria mengatakan bahwa mereka sering menelan air mani dan tidak memakai kondom ketika berhubungan seksual sebagai ungkapan rasa kasih dan cinta (biasa dilakukan pada pacar atau "suami" PSK sendiri). Sedang sebagian kecil responden mengaku mau menelan air mani hanya pada pelanggan yang masih muda dengan alasan rasanya seperti degan. Ketiga, kebutuhan ekonomi (uang), ketika imbalan jasa yang ditawarkan pelanggan tinggi maka PSK waria akan melayani dengan baik tanpa mengindahkan perilaku untuk tetap patuh. Sedang untuk memeriksakan kesehatan secara rutin, mereka mempunyai kendala yaitu tidak mau mengeluarkan uang transportasi, waktu, kalau siang mereka istirahat (tidur), kepercayaan pada pengobatan alternatif (obat tradisional).

Menurut Gea (2003) bahwa imbalan penting dalam memotivasi seseorang, banyak orang mau melakukan sesuatu termotivasi oleh imbalan yang bakal diterima sesudahnya, semakin imbalan itu penting bagi mereka, motivasi mereka untuk mengejarnya semakin besar.

Salah satu cara agar waria bisa memenuhi kebutuhan sendiri adalah dengan memiliki penghasilan sendiri. Mereka bisa mendapatkannya dengan cara bekerja agar bisa memenuhi kebutuhan hidup. Menurut As'ad (1981 : 46) bekerja adalah aktivitas manusia baik fisik maupun mental yang pada dasarnya adalah bawaan dan mempunyai tujuan yaitu mendapatkan kepuasan. Di dalam dunia kerja, tidak semua bidang pekerjaan dapat menerima kehadiran waria. Ada semacam ciri tertentu, pada pekerjaan yang dapat ditekuni, oleh waria secara total, misal salon, berdagang, dan beberapa pekerjaan seni (dunia hiburan). Keadaan diperburuk oleh latar belakang pendidikan yang rendah (akibat tekanan sosial), tidak adanya kesempatan kerja bagi waria yang disediakan sektor pemerintah dan swasta. Sedang sektor pekerjaan informal yang identik dengan dunia kewariaan adalah salon, dan dunia hiburan. Padahal tidak semua waria mempunyai bakat bekerja di salon ataupun dunia hiburan, di satu sisi tekanan dan diskriminasi masyarakat masih terus berlangsung, namun mereka juga manusia biasa yang mempunyai kebutuhan hidup untuk dipenuhi sehingga alternatif pilihan pekerjaan mereka adalah menjadi Pekerja Seks Komersial (PSK). 30 responden menjadi PSK karena ingin mendapat penghasilan untuk hidup. Mereka memiliki menjadi PSK karena dengan menjadi PSK tidak memerlukan pendidikan dan keterampilan khusus. Bekerja di bidang prostitusi banyak mendatangkan uang dengan lebih mudah. Saat ini tarif normal dalam sekali "main" antara Rp. 10.000,- sampai Rp. 15.000,-. Tarif tersebut bisa berubah bisa lebih banyak bahkan lebih sedikit tergantung tamu yang datang dan kecantikan dari waria sendiri.

Pada lingkup sosial, motivasi ekonomi yang tinggi untuk mendapatkan uang (penghasilan) pada seorang individu maka ia akan cenderung melakukan perilau yang tidak patuh. Hal ini terjadi karena uang menjadi prioritas 
utama, uang yang mereka peroleh akan dikelola untuk mencukupi kebutuhan fisiologis mereka, ini sesuai dengan teori hierarki kebutuhan Maslow, bahwa kebutuhan fisiologis adalah kebutuhan yang berada pada prioritas utama dalam usaha pemenuhannya, kebutuhan yang harus dipenuhi antara lain; makan, membeli baju, make up, dan kebutuhan sehari-hari lainnya, membayar kontrakan rumah atau kost, karena mayoritas responden (PSK waria) tinggal di rumah kontrakan atau kost. Ditambah jika masih harus membantu membiayai hidup keluarga (orang tua, saudara), pacar atau 'suami'.

Hasil penelitian yang menunjukkan bahwa tidak ada hubungan antara motivasi ekonomi dengan kepatuhan dalam mencegah penularan HIV/AIDS bisa terjadi karena jumlah penghasilan PSK waria yang relatif rendah dan tuntutan kebutuhan yang makin meningkat dan mahal, membuat mereka terkadang meninggalkan perilaku untuk tetap patuh mencegah penularan HIV/AIDS. Contoh kasus, ketika seorang PSK waria mendapatkan pelanggan dengan imbalan besar, asal melayani tanpa memakai kondom, maka PSK tersebut akan meyalani dengan senang hati. Begitu juga ketika seorang PSK belum mendapat pelanggan (1 hari atau lebih), ketika datang seorang pelanggan maka mereka akan tetap melayani sesuai dengan permintaan pelanggan, berapapun bayarannya.

Seperti kasus yang menimpa pada 3 orang PSK waria yang biasa mangkal di daerah $\mathrm{Jl}$. Kembang Kuning, usia mereka yang sudah di atas 45 tahun membuat pelanggan yang datang berkurang, sedangkan mereka harus tetap mendapatkan penghasilan karena mereka tidak punya pekerjaan lain selain menjadi PSK, sehingga walaupun mereka mengetahui bahaya HIV/AIDS, tapi karena tuntutan untuk tetap hidup tinggi, maka mereka melayani setiap pelanggan yang datang tanpa pernah memakai kondom, mereka juga tidak pernah melakukan pemeriksaan secara rutin dengan alasan uang yang mereka dapatkan lebih baik untuk membiayai kebutuhan hidup sehari-hari. Tingkat motivasi ekonomi yang tinggi seperti pada kasus di atas menyebabkan banyak PSK waria yang berperilaku seksual yang tidak aman. Penghasilan PSK waria yang sedikit (mayoritas penghasilan < Rp. 400 ribu) serta tingkat kebutuhan yang ingin dipenuhi, memungkinkan mereka melakukan tindakan kriminal misalnya mencuri atau mencopet, ketika mereka mendapat seorang pelanggan, mereka tak segan untuk mencuri atau mencopet uang, dompet, HP, perhiasan dari pelanggan. Istilah mencuri dari pelanggan dikenal dengan istilah sinyop. Praktek mencuri ini mereka lakukan bersamaan saat melayani pelanggan.

Motivasi didefinisikan sebagai kekuatan atau daya dorong yang menggerakkan sekaligus mengarahkan kehendak dan perilaku seseorang dan segala kekuatannya untuk mencapai tujuan yang diinginkan (Gea, 2003). Motivasi memuaskan pelanggan diharapkan mampu untuk memberikan kepuasan pada pelanggan, karena dengan pemberian jasa yang memuaskan pelanggan akan menjadi setia. Kepuasan pelanggan adalah suatu keadaan dimana keinginan pelanggan dan keperluan pelanggan dipenuhi dan merupakan elemen penting dalam menyediakan pelayanan (M. Ramdan, 2004). Secara teori ekonomi jika kita memberikan pelayanan yang memuaskan kepada konsumen, maka konsumen akan merasa puas dan suatu saat jika konsumen membutuhkan jasa, ia akan kembali pada penyedia jasa tersebut. Motivasi untuk memuaskan pelanggan yang dilakukan PSK waria bertujuan untuk mendekati, mendapatkan dan mempertahankan konsumen atau pelanggan, sehingga mampu menarik dan mempertahankan loyalitas pelanggan.

Hasil penelitian yang menunjukkan tingkat motivasi ekonomi memuaskan pelanggan tinggi dengan tingkat kepatuhan yang juga tinggi, ternyata tidak menjadikannya sebuah hubungan yang signifikan. Hal ini bisa terjadi karena adanya tuntutan dari pemakai jasa atau pelanggan untuk tidak memakai kondom. Selain itu motivasi memuaskan pelanggan sendiri dipengaruhi oleh beberapa faktor; Pertama adalah penampilan pelanggan (umur, personal hygiene) ada sebagian PSK waria yang tidak mau melayani pelanggan yang sudah tua dengan alasan jika mereka melayani seperti melayani orang tua sendiri, penampilan pelanggan yang kelihatan bersih atau kotor juga mempengaruhi, misal saat ada pelanggan yang berpenampilan agak kotor walau dengan bayaran yang besar mereka tidak mau melayani, untuk melakukan "mandi kucing" para PSK sangat memilih dengan pelanggan seperti apa ia harus melakukan, kalaupun ada pelanggan dengan imbalan jasa yang ditawarkan besar untuk melakukan "mandi kucing" namun penampilan pelanggan kotor maka PSK tidak akan mau menuruti, tapi jika PSK waria kondisi keuangannya kurang maka ia akan melayani seperti apapun penampilan pelanggannya. Kedau, perlakuan pelanggan terhadap PSK waria, hal ini dinilai dari tingkat kesopanan pelanggan dalam berbicara dan memperlakukan waria. Ketiga, besarnya imbalan jasa yang ditawarkan pelanggan dan keempat faktor emosi (mood) dari PSK waria sendiri.

Contoh kasus, ketika seorang PSK mendapat seorang pelanggan yang muda, tampan dan sangat menarik perhatian, maka PSK akan dengan senang hati melayani pelanggan tersebut sepuasnya tanpa mempedulikan besarnya imbalan jasa dan perilaku kepatuhan. Contoh lain adalah ketika seorang PSK mendapat pelanggan dengan 
imbalan jasa yang besar maka mereka akan berupaya untuk memberikan kepuasan yang optimal, sehingga pelanggan tersebut bisa puas dan loyal. Imbalan jasa (uang) sangat berperan penting dalam semua faktor yang berhubungan dengan kepatuhan, ketika tawaran yang diberikan sangat tinggi maka bahaya HIV/AIDS yang telah diketahui dengan baik akan dikesampingkan.

\section{SIMPULAN}

Faktor predisposisi yaitu tingkat pengetahuan, motivasi ekonomi, motivasi memuaskan pelanggan tidak mempunyai hubungan dengan kepatuhan dalam mencegah penularan HIV/AIDS pada PSK waria Kota Surabaya, hal ini terjadi karena faktor tuntutan ekonomi tinggi. Para PSK lebih mengutamakan kepuasan pelanggan sehingga pendapatan atau penghasilan mereka bertambah, daripada berlaku patuh dengan memakai kondom.

\section{SARAN}

Gerakan mencegah penularan HIV/AIDS tidak sekedar pada gerakan kondomisasi dan vending machine (mesin kondom), tapi lebih pada perubahan perilaku untuk tidak menjadi PSK lagi.

\section{DAFTAR PUSTAKA}

AusAid. 2002. Buku Pegangan Konsuler: HIV/AIDS. Yayasan Kertpraja dan Yayasan Burnet Indonesia.

BKKBN. Cerita Remaja. www.bkkbn.go.id diakses tanggal 20 Januari 2015

Depkes RI. 2011. Subdit PMS dan HIV/AIDS. Ditjen P2MPL. Jakarta

Kemenkes RI. 2014. Ditjen PP \&PL Statistik Kasus HIV/AIDS di Indonesia. Jakarta

Gea, Antonius Atosokhi. 2003. Character Building, Membangun Relasi dengan Diri Sendiri. Jakrta. Elex Media Computindo.

Harahap, Syaiful. Menyibak realitas waria di Indonesia. $\quad$ www.rad.net.id/Aids/hindar. diakses tanggal Agustus 2016

M.Ramdan.

www.deliveri.org/guidelines/misc/proj_pap ers/pp_31.htm. Kepuasan Pelanggan. diakses tanggal 1 Agustus 2015

Puspitosari, Hesti. 2005. Waria dan Tekanan Sosial. Malang. UMM Press 